\title{
Oracle of Doom or Oracle of Salvation? A New Interpretation of Animal Metaphors in Isa 31:4-5 in the Light of Rhetorical Analysis
}

\author{
BARTŁOMIEJ SOBIERAJSKI \\ Major Seminary of The Society of Christ Fathers in Poznań, Poland \\ ks.b.sobierajski@gmail.com, ORCID: 0000-0003-3007-787X
}

\begin{abstract}
This article seeks to clarify the meaning of animal metaphors contained in Isa 31:4-5. Difficulties in interpreting these metaphors are associated with the Hebrew syntax as well as the proper reading of the symbolism of the characters and animals found within these verses. These issues also raise the question of the message of the whole prophecy: is it an oracle of doom or of salvation? The article provides an overview of previous attempts to explicate the metaphors and proposes a new interpretation of them. It turns out that Isaiah consciously and intentionally uses some ambiguous images and formulas in order to make a specific impression on the addresser. Such literary devices are characteristic of his statements from the last period of his activity (705-701 BC). The new interpretation of animal metaphors presented in this study also results from the structure of the oracle, which has emerged through the use of Hebrew rhetoric methods.
\end{abstract}

Keywords: Isaiah, Isa 31:4-5, animal metaphors, rhetorical analysis

In the history of interpretation of Isa 31:4-5 a multitude of disparate and conflicting interpretations have been proposed. There is no fundamental agreement concerning the metaphorical meaning of the lion and the young lion in v. 4 or flying birds in v. 5. What is the motif of these two comparisons: do they announce doom or salvation? Or does one of them announce doom while the other - salvation? If so, why are they bound together? Or maybe the prophecy transformed its message during ages. What are their functions hidden between the verses condemning the Israelites' behavior (31:1-3 with the typical lament expression - הiו ) and the part announcing the defeat of the Assyrian aggressor (vv. 8-9)? These ambiguities are also reflected at the syntactical level of the text. What does the expression from

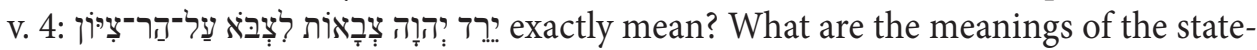
ments that YHWH shall "go down to fight upon Mount Zion" or that he shall "go down to fight against Mount Zion"? One can also find other ambiguities and difficulties in interpretation. In fact, this part of the Isaianic text is a real crux interpretum for many exegetes. 
The article seeks to resolve at least a part of the aforementioned exegetical problems through an exploration of the real meaning of the metaphors of a growling lion (v. 4) and hovering birds (v. 5), hoping to answer the following questions: What is hidden behind the images of a lion and birds? To whom do the animals refer to? Can one find other hidden subjects, e.g. behind the image of shouting shepherds (v. 4)?

My research is divided into two sections. The first is dedicated to literary issues, placing the prophecy in its own literary and historical context. Then, a structure of the passage pointing out its internal dynamics will be proposed in the light of the rhetorical analysis of the text. In the second part, a new interpretation of the two animal metaphors is advanced. A new understanding of Isaiah images of lion and birds in chap. 31 is supported by remarks concerning the Semitic rhetoric made in the first part of the study. ${ }^{1}$

\section{The Prophecy in Its Context}

\subsection{The Literary Context of Isa 31}

Within the section Isa 28-35, one can distinguish smaller parts according to the term הim occurring six times there. ${ }^{2}$ It stands as an initial term of six prophecies concerning primarily Jerusalem and her citizens $(29: 1.15 ; 30: 1 ; 31: 1)$, but also Samaria $(28: 1)$ and Assyria (33:1). Such a scheme allows to treat chap. 28-33 as the sequence of the interwoven oracles of judgment and salvation. ${ }^{3}$ A motif that binds them together can be the reign of YHWH (32:1; 33:22): God wants to remove depraved layers of leadership from Jerusalem by using the Assyrian Empire as a tool. However, the exaltation of YHWH discloses his majesty and power both to Israel and other nations

1 This article is based on the conclusions presented as the S.S.L. (Licentiate in Sacred Scripture) thesis: Oracle of Doom or Oracle of Salvation? An Exegetical Study of Isaiah 31. The dissertation was written under the supervision of Prof. Alessandro Coniglio and defended on January 30, 2018, at the Studium Biblicum Franciscanum in Jerusalem.

2 One can assume that Isa $28-35$ is a separate unit because it is the longest poetic text in the section of Isa 28-39. The last part (chap. 36-39), written in prose, is the so-called Historical Supplement, which presents the events of $701 \mathrm{BCE}$ and introduces the message of hope that stays at the beginning of Deutero-Isaiah (chap. 40).

3 As an example, one can show the outline presented by Gary Stansell ("Isaiah: 28-33," 71):

1. 28:1-4 (judgment), 28:5-6 (salvation), 28:7-22 (judgment), 28:23-29 (salvation);

2. 29:1-4 (judgment), 29:5-8 (salvation), 29:9-14 (judgment);

3. ה: 29:15-16 (judgment), 29:17-24 (salvation);

4. הוזי 30:1-17 (judgment), 30:18-26 (salvation);

5. הוֹי 31:1-4 (judgment), 31:5-32:8 (salvation), 32:9-14 (judgment), 32:15-20 (salvation);

6. יה: 33:1 (judgment), 33:2-24 (salvation). 
(cf. 28:5-6; 29:6; 30:30). This finally leads to the salvation of Zion, whose model is the miraculous salvation of Jerusalem in 701 BCE $(28: 16 ; 29: 8 ; 33: 20) .{ }^{4}$ Characteristically, certain patterns are repeated in these oracles. First, God opposes and fights against not only the enemies of Israel (e.g. Assyria), but the chosen people as well. Second, God uses other nations - especially Assyria - as tools. The decimation of the Assyrian army in 701, however, is not an expression of YHWH's powerlessness, but rather a manifestation of his direct action, without the usage of any instrument. Third, the miraculous saving of Jerusalem in the eyes of Isaiah is a failure of human intent. These motives appear, among others, in the following oracles.

The first (Isa 29:1-14) refers to Ariel. Although there are many attempts to show the origin of this word, without any doubt, it designates Jerusalem. ${ }^{5}$ The characteristic motif of this passage is the proceeding of YHWH in the fight against Jerusalem, suggesting an instrumental reading of Assyria's role and her attempt to conquer the capital.

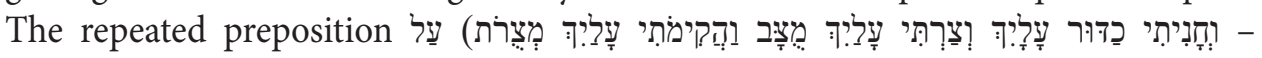
"and I will encamp against you round about; I will besiege against you with towers and raise siegeworks against you," in 29:3) indicates the military reality of capturing the city. Apart from that, it points out that the opponents of God are not only the nations, waging war with Judah, but also the chosen nation itself

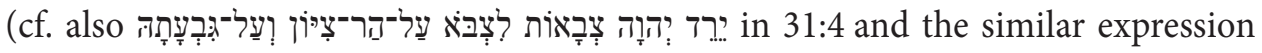

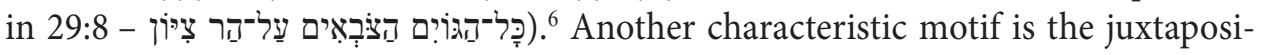
tion of Assyria and Ariel as opponents of YHWH. For both of them, their victory is ultimately compared to an illusory dream (in v. 7 for Ariel, in v. 8 for Assyria). The miraculous salvation of Jerusalem does not make it boast and joy, but denounces false human wisdom (vv. 9-12; cf. the term חָָָ in 29:14 and 31:2), which becomes its humiliation (v. 4).

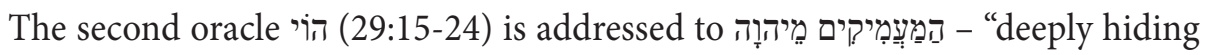

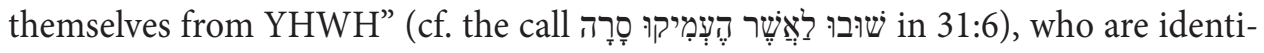
fied as those whose "actions are covered with darkness" (v. 15). Taking into account the context of the section of chap. 28-39, the allusion to the secretly anti-Assyr-

4 Cf. Seitz, Isaiah 1-39, 205-206; Sweeney, Isaiah 1-39, 357.

5 Even the occurrence of this word in various consonantal variants (הראל, אראיל ,אריאל, אראל) leads to the conclusion that it is likely to be borrowed from another language and adapted to the Israelite consciousness, oftentimes in different ways. The name "Ariel" may have connotations with the word "lion," which would indicate an honorable heroic title (cf. 2 Sam 23:20; Godbey, "Ariel, or David-Cultus," 262). In the Book of Ezekiel, it probably denominates the central part of the altar (firebox), on which the sacrifice, the so-called "God's hearth," was offered (cf. Feigin, "The Meaning of Ariel," 132; Zimmerli, Ezekiel 2, 426). The Akkadian word arallu stands for the land of the dead (cf. Albright, "The Babylonian Temple-Tower," 138; Wildberger, Isaiah 28-39, 72). On the basis of the Mesha Stele, some exegetes advocate understanding as figurines, statues of divinities (cf. Feigin, "The Meaning of Ariel," 134). On the other hand, based on the Qumran lessons, a connection with the original name of Jerusalem began to be found (cf. Youngblood, "Ariel, «City of God»", 458-460).

6 Cf. Sobierajski, Antropologiczny wymiar proroctw, 232-233, 244. 
ian negotiations during the Sennacherib's sitting on the throne (705 BCE) can be seen. "Actions covered with darkness" may have an ambiguous meaning. On the one hand, the direct confrontation with Assyria could have been doomed to failure at the outset, hence the search for coalition partners had to involve secret negotiations carried out by the kingdom of Judah. ${ }^{7}$ On the other hand, it may also be an allusion to the hindering advice from YHWH, but acting only according to one's own plan (cf. vv. 16.18.24). However, there is no doubt that the addressees are the elites of the capital (if not in political matters, certainly in everyday life, especially in judiciary - cf. 29:21). What is characteristic is that their identity is defined as -

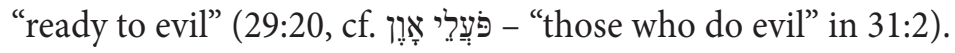

The preceding immediate context of the analyzed passage is the הin oracle in chap. 30, which in many places looks very similar to chap. 31 . The parallel can be seen at the very beginning of the two woe-oracles, which are directed to those who seek refuge in Egypt. The essence of the offense is self-reliance as well as not seeking the advice in YHWH (30:1.2.9; cf. 31:1). The announced ineffectiveness of Egypt's help (root עז in 30:5.7; cf. 31:3) and the voidness of her protection (31:3)

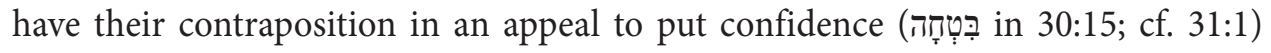
in God. The second parallel can be found in the description of future prosperity (30:19-26), which foreshows both, proceeding YHWH and affluent life in a favorable environment. The reference to "that day" (31:7, cf. 30:26) is strictly connected with defiling silver-covered idols and gold-plated images and throwing them away (30:22; cf. 31:7). The third powerful parallel refers to Assyria and her collapse. Significantly, the prophet first proclaims the intervention of YHWH by the invasion of the Assyrian army (30:27), but then the situation changes: God no longer recognizes Assyria as his instrument and foretells her destruction (30:31-33). ${ }^{8}$ It is mostly depicted by the motif of fire (30:27.30). The end of the whole oracle, which shows the place called Tophet, is significant: "His firepit made both deep and wide, with fire and firewood in abundance, and the breath of the Lord, like a stream of sulfur, setting it afire" (30:33), because brings to mind analogous end in chap. 31 ("Says the Lord who has a fire in Zion and a furnace in Jerusalem" - 31:9). What is important, "the final hostility of YHWH towards the (Assyrian) empire is not an expression of the ineffectiveness of his intentions; he has foreseen it «for a long time» (מאתמוּמול - 30:33) and the next stage is his independent, direct action." Below I will show that similar patterns are also found in the prophecy of Isa 31.

7 Cf. Blenkinsopp, Isaiah 1-39, 408.

8 The recognition of the presence of God in the Assyrian army is supported by the analysis of the phrase:

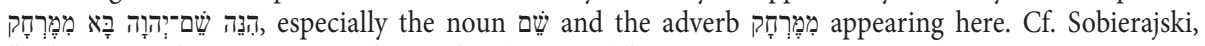
"«The Name of YHWH Comes from Afar» (Isa 30:27)," 431-445.

9 Sobierajski, “"The Name of YHWH Comes from Afar» (Isa 30:27)," 444. 


\subsection{The Composition}

\subsubsection{Structure of the Prophecy}

The analyzed passage of Isa 31 can be divided into four units: (1) verses 1-3, (2) verses $4-5$, (3) verse 6 , and (4) verses $7-9 .^{10}$

The rhetorical unity of the first part is testified by the terms "Egypt" and "horses"

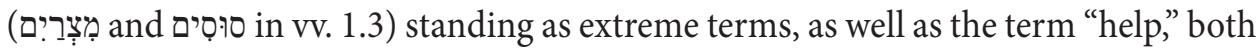

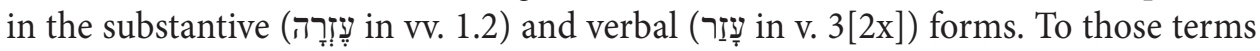
one can also add "chariot" (רָכָ in v. 1) and "horsemen" (ספָר in v. 1) as belonging to the same semantic field associated with the things in which Israel seeks support. The messenger formula in the beginning of the next part (v. 4) stands also as a formal criterion, appointing the end of the unit preceding it. The foregoing formal criteria are supported by the content ones. Besides the semantic field mentioned above, consisting of names describing the reality of help for Israel, there is also another field

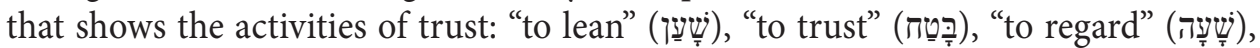
"to seek" (שרฺָּ ; all of them in v. 1) and a third one in some sense opposing the one

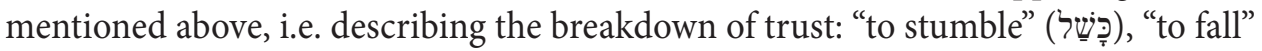

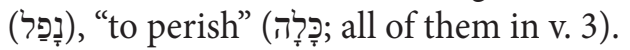

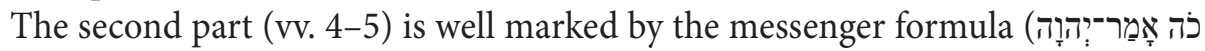
in v. 4) serving as a function of the initial term. For the unity testifies, above all, to the form, i.e. two comparisons constructed in the same way (.... ... כִ in vv. 4.5), as

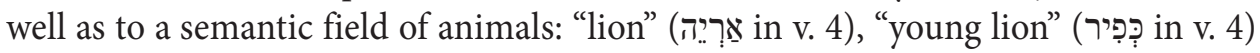

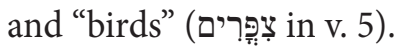

The third part (v. 6) is distinguished from the rest of the text by its syntactical form: it is a direct appeal (grammatically: imperative) to turn back to God. ${ }^{11}$ The unity of this part is confirmed by the predicate in imperative ("turn back" - שיוּבוּ)

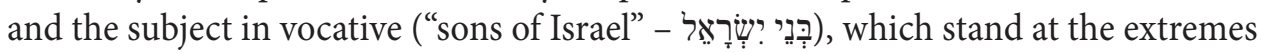
of the part. ${ }^{12}$

10 The terminology used to designate the rhetorical units (from the smallest one: term - member - segment - piece - part - passage [equivalent of 'pericope'] - sequence - section - book) and the terms designating the rhetorical function of symmetrical elements (initial, final, extreme, median and central terms) follows: Meynet, Rhetorical Analysis, 374-375.

11 For the vocative as a marker denoting the beginning of a part of the text: van der Lugt, Cantos and Strophes, 79.

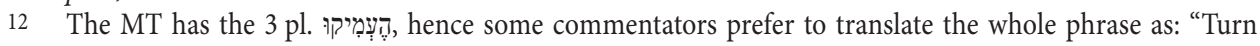
back to him to whom the children of Israel have made a deep betray," treating of the relative clause (Kaiser, Isaiah 13-39, 250; Irwin, Isaiah 28-33, 115; Wildberger, Isaiah 28-39, 217; Watts, Isaiah 1-33, 477-478). However, here a vocative fits much better: "Turn back to him whom you have made a deep turning aside, sons of Israel!," (Oswalt, The Book of Isaiah, 573; Beuken, Isaiah II, 190), all the more as the subject of the primary clause does not have to be the same as that of the relative clause. Cf. Joüon - Muraoka, A Grammar, $\$ 158$ n; Isa 54:1; Ezek 26:17; 29:3. 
The last fourth part (vv. 7-9) is delimitated by two technical expressions, which

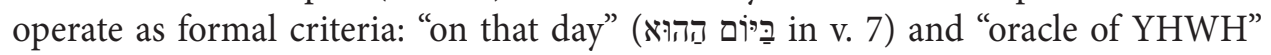
(נִאטם־י:הוָה in v. 9). From the syntactical view, one can also find similar constructions of relative clauses standing as extreme terms, e.g. a human had the idols that

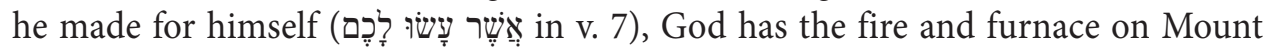

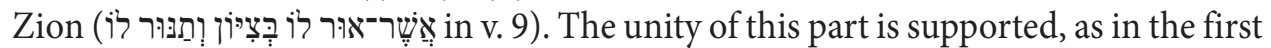
part, by two semantic fields. The first contains things that are related to human safe-

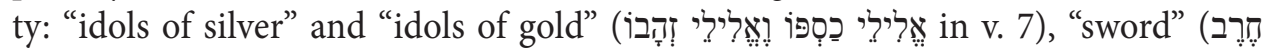
in v. 8[3x]), "rock" (סָל in v. 9) and "standard" (סָ in v. 9). The other constitutes

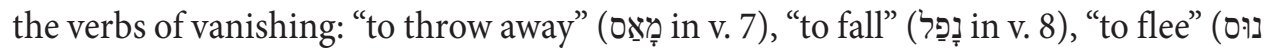
in v. 8), "to pass away" (עָבָ in v. 9) and "to be shattered" (חָתָת v. 9).

\subsubsection{Rhetorical Dynamics of the Text}

The four parts, of which the passage in question is composed (vv. 1-3, 4-5, 6, 7-9), form the structure ABA'B'.

The analysis of rhetorical dynamism has to be considered on two complementary and interwoven planes. The first one assumes that the passage is composed of the two oracles: judgment (vv. 1-5) and salvation (vv. 6-9). Both of them, by contrast, represent two alternative situations in Israel. The former shows the current state. The chosen people turns to Egypt for help (v. 1), but it is immediately indicated that this will be unsuccessful (v. 3). ${ }^{13}$ YHWH's intervention is announced as a protest

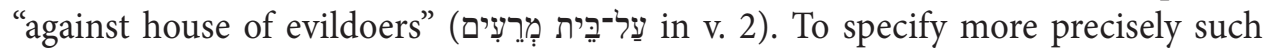
an intervention in the second part (vv. 4-5) is introduced, combined by two comparisons. The continuity of thought underlines the similar construction "fight against

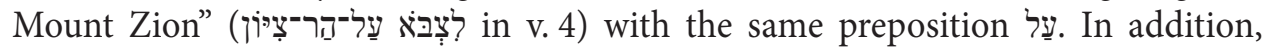
the connectivity of both parts is emphasized by the term "YHWH" (vv. 3.4) standing as a median term. The cause-effect dependency is brought in by the conjunction

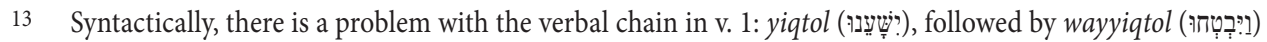

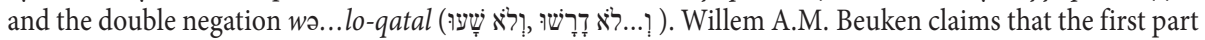
"expresses the current situation ('who go down... and rely'), while v. $1 \beta$ relates the process which led up to it and is still going on. This past that continues in the present is best translated by the present verb forms ('who trust... but do not look... or consult')." Cf. Beuken, Isaiah II, 189. Similar situation can be found

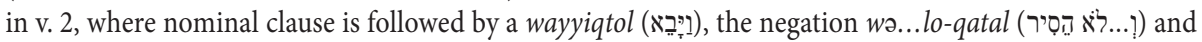
wəqatal (וٕ? ). Hans Wildberger suggests that should be translated in the past tense just because of the qatal verbs preceding it (cf. Wildberger, Isaiah 28-39, 205-206). Approving Beuken's proposal one can also notice the fact that non-perfective conjugation (yiqtol) signifies, among other things, the iterative past in main clauses (cf. Waltke - O’Connor, An Introduction, $\$ 31.1 .1 . b$ ), whereas the perfective (qatal) - "can be correlated with present-time reference as it is understood in English [...]. In the persistent (present) perfective, the suffix conjugation represents a single situation that started in the past but continues (persists) into the present" (Waltke - O’Connor, An Introduction, $\$ 30.5 .1 . c$ ). Having this in mind, I propose to translate it as the English present perfect form, with the meaning of v. 1: they are continuously asking Egypt for help because at some moment they decided to trust more in its chariots than in God ("Woe for those who go down to Egypt for help, on horses lean, and have trust in chariot"); analogously v. 2. 
which - together with the messenger formula - performs the function of a central term (for vv. 1-5, and then for vv. 6-7 - together with the stereotype formula "on that day"). One also finds an analogy by appealing to the multiplicity of those who had to

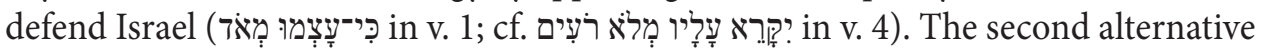
situation of the Israelites presupposes their conversion, expressed in their return to YHWH (v. 6). Although, the link of this part to the next one (vv. 7-9) is no longer so rhetorically exposed, but there is a clear passage of effect, suggested by the conjunction 'כ..$^{14}$ The sign, which indicate the unity of the second oracle (vv. 6-9), might also be the relative clause with אֶֶָׁ (vv. 6.7.9) repeated three times. ${ }^{15}$ This dynamics can be schematically presented as follows:
$\mathrm{AB}(\mathrm{vv} .1-5)$
Fate of Israel deviated from YHWH

A'B' (vv. 6-9)

Fate of Israel returned to YHWH

The symmetry of these bi-parts is underlined - from the rhetorical side - above all by the presence of the expressions standing as central terms, that are composed of

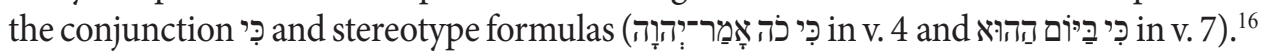

Such an approach must be completed and integrated with the second one, showing parallels between each part. The parallel between A and A' is emphasized by the contrast of Israel's behavior, expressed by the verbs of motion. As before, the Israelites went to Egypt for help and they did not seek God (v. 1), so now Israel is

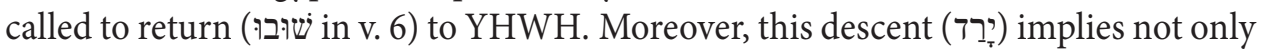

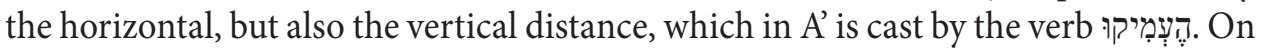
the other hand, on the semantic basis, it is important to notice the opposite of the attitude: the deep "turning aside" (סָרָה) of Israel is contrasted to the word of YHWH, which he "has not turn aside" (לא הִסִיר in v. 2), he does not change. The parallelism also emphasizes the presence, only in these parts, of the name "Israel." Although

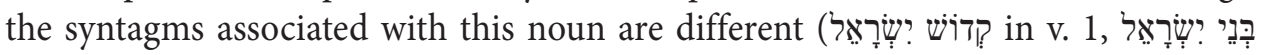
in v. 6), but one can see the bridge formed between the parts. The "sons of Israel" do not recognize their belonging to YHWH - the "Holy of Israel," and they seek strength and help in foreign powers, instead of looking for them in God. Thus, despite the volume difference of part A and part A', they show a clear parallelism. On the other hand, the relationship between B and B' results from their function, which is to show the effects of these particular attitudes of Israel: either rejecting YHWH or returning to him. Formally, the parallelism is primarily emphasized by the final

\footnotetext{
14 Cf. Oswalt, The Book of Isaiah, 575; Sweeney, Isaiah 1-39, 406.

15 In v. 4c, there is also the אָָׁׁ conjunction, but in an adverbial phrase of time (meaning "when").

16 Such a structure is confirmed by the observation made by Marvin A. Sweeney (Isaiah 1-39, 407): "It is noteworthy that chap. 31 makes little sense without vv. 6-9. If the passage was designed to condemn alliance with Egypt, it can hardly succeed in that it fails to present an alternative strategy until vv. 6-9. Egyptian alliance is condemned, but the images of destruction in vv. 1-5 hardly provide a full basis for abandoning the position. As vv. 4-5 make clear, Jerusalem is doomed whether Egypt attempts to help or not. Vv. 6-9 provide the basis for positive action."
} 
terms "Jerusalem" and "Zion," which marks the ends of these units. It is true that in part B they do not appear side by side, but, by treating each of the comparisons as the separate pieces, one can see that the terms stand always at their ends (vv. 4.5; the same as in part B', already together at the end of the oracle - v. 9). The term "YHWH" fulfills an analogous function: indicating the end: in part B in the construct

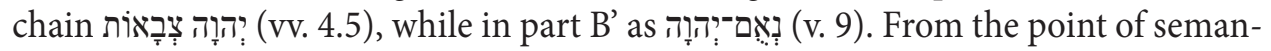
tics, this parallelism is expressed by the descriptions of the behavior of the lion and of Assyria. While the lion is not afraid about the fullness of shepherds and "by their

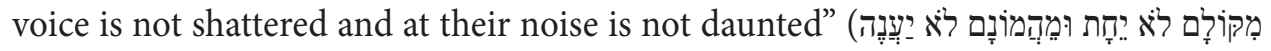
in v. 4), Assyria behaves in an opposite way: "he shall flee itself from a blade of sword [...] his rock in terror shall pass away, and shall be shattered by the standard his of-

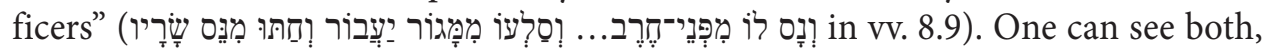
the similarity of words (the verb חָּ in vv. 4.9) and the sentence structure (using the preposition $\triangleright$ ). Thus, the diagram of the dynamics of the whole oracle presented above can be supplemented and presented as follows:
A (vv. 1-3)
Deviation of Israel
B (vv. 4-5)
$A^{\prime}($ v. 6$)$
God's rise against Israel
B' (vv. 7-9)
Call to return
God's rise against Assyria

The understanding of the message of the two comparisons (vv. 4-5) will be, on the one hand, based on their linkage with part A from the causal point of view and, on the other hand, their significance should be read by looking at the parallel part B. Having outlined the structure of the oracle, one can therefore see the premise that the animal metaphor may combine two elements: punishment for deviation (taking into account its correlation with vv. 1-3) and the character of this punishment (which somehow will be similar to the character of the salvation from vv. 7-9). Therefore, if the salvation will be done by God himself and not according to the human thoughts ("Assyria shall fall by a sword, not of mortals" - v. 8), then we expect to find similar thoughts in the part B of the oracle (vv. 4-5). The following section will show that Isaiah gives such a meaning to these comparisons.

\section{A New Proposal of Interpreting the Two Metaphors}

\subsection{The Metaphor of the Lion}

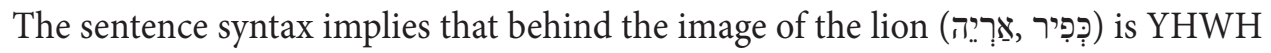
himself (in both parts of the comparison the lion and YHWH are the only ones in sg.). All exegetes accept this interpretation, and it is also consistent with the li- 
on's symbolism in the Middle East and on the pages of the Old Testament. ${ }^{17}$ "The most powerful among the wild beasts, which does not turn back before any" (Prov 30:30); it is famous for its strength (2 Sam 1:23), courage (2 Sam 17:10) and roaring (Ezek 22:25). Particularly, the latter feature was used to compare YHWH to the lion because of his loud voice aligned just to the lion's roar (the verb שָ in Job 37:4; Amos 1:2, both also with the noun iip used in Isa 31:4). The Book of Hosea brings a direct comparison of God to the lion (and also to other wild animals: leopard and bear - cf. Hos 13:7-8) in the context of the Syro-Ephraimitic War (the beginning of Isaiah's activity): He will be "as a lion to the house of Judah," who "tears the prey and departs" (Hos 5:14). ${ }^{18}$ The latter case is particularly important as some of the exegetes maintain that YHWH could not be represented in the image of the lion tearing apart his prey - Jerusalem. ${ }^{19}$ However, if Hosea, contemporary to Isaiah but operating in the Northern Kingdom, illustrates the action of God by the image of the wild beast against Ephraim, one should be open to the same interpretation in Isa 31:4 regarding the Southern Kingdom.

The enemies of Israel were also described as lions. As an example, one should mention Amos 3:12, in which - in an ironical way - the help for Israel is showed: the shepherds are able to rescue from the lion's mouth "only two legs or a piece of an ear." In the context of Isaiah, the invasion of Assyria is compared to "a roaring lion

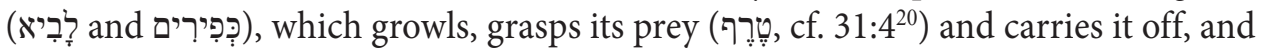
there is no rescue (מֵצי cf. 31:5)" (5:29). ${ }^{21}$ The Assyrian rulers during the war expeditions described themselves willingly as lions. ${ }^{22}$ The last example (Isa 5:29) is significant, because Assyria is clearly portrayed for Isaiah as a tool in the hands of YHWH (cf. 5:26; 10:5-6.15); however, it rebels against the task assigned by God (10:7). In this light, in the image of the lion from chap. 31 one cannot directly see YHWH, but Assyria, though it remains only the tool in his hand.

There is a discussion whether behind the image of "shepherds" - רעים - some specific people or nation can be seen. The problem with the entire image is that the shepherds are not normally perceived as aggressors against sheep nor is the lion their defender. The verb רָָָ has specific, theological implications in Isaiah. Together with the רִּ , it is often used to describe the future condition: either the desolation $(5: 17 ; 27: 10)$ or peace provided by the presence of the only one shepherd - YHWH

17 Cf. Kaiser, Isaiah 13-39, 316; Seitz, Isaiah 1-39, 225; Motyer, Isaiah, 202; Blenkinsopp, Isaiah 1-39, 427; Childs, Isaiah, 232; Goldingay, Isaiah, 177; Wildberger, Isaiah 28-39, 221; Watts, Isaiah 1-33, 479; Roberts, First Isaiah, 404.

18 A broader discussion of the symbolism and metaphors of animals, especially lions, also with regard to deities, see: Nielsen, "I am Like a Lion to Ephraim," 184-197.

19 Cf. Beuken, Isaiah II, 235-236; Wildberger, Isaiah 28-39, 257-258.

20 The noun טרֶר normally describes the prey of wild animals, very often linked with the image of the lion (Gen 49:9; Num 23:24; Deut 33:20; Job 4:11; 38:39; Ps 7:3).

21 The other examples are: Jer 2:14-15; 4:7; 25:38; Nah 2:12; Zech 11:3.

22 Cf. Tawil, "El león y las aves," 161-162. 
(14:30), also in the eschatological perspective (11:7). ${ }^{23}$ The motif of the appropriate ruler, who could provide peace for Judah, is leading especially in the first part of Proto-Isaiah (chap. 1-12). Such a task does not fit the succeeding kings or the leaders of Jerusalem (cf. 1:10.23; 3:1-4.12-14; 5:8-23; 7:10-12; 9:13-15; 10:1), hence YHWH announces the awakening of the ideal ruler - Emmanuel (chap. 7). The prophecy of Isa 8:23b-9:6 shows his introduction to the throne, and in chap. 11 - description of his reign. ${ }^{24}$ What is more, the "shepherd" can also refer to the kings in the ancient Near East. ${ }^{25}$ The use of the plural רעים, in chap. 31, may thus be a conscious contrast to the other rulers (whether nations or individuals) with the very one who will reign according to the will of YHWH. In this light, "shepherds" (31:4) can mean both, Jerusalem's leaders, seeking help in Egypt, and Egypt itself, which for Judah seemed to be an effective guarantor of peace. ${ }^{26}$ Such understanding is confirmed by v. 3 , in which the annihilation of the helper (Egypt) and the helped one (Judah) is equally pronounced.

These "shepherds" are characterized by two nouns describing their voices: קic ("voice") and הדמוֹ ("noise, rumble"). Both of them have the specific usage in Isaiah (besides the use of קi in the situation of speech or cry, e.g. Isa 10:30; 15:4; 24:14; 28:23): they often occur in theophanies $(6: 4 ; 29: 6 ; 30: 30-31)$ and similar to them, the descriptions of YHWH's moving into battle (13:4; 33:3), or among the features that describe the opponents of God $(17: 12 ; 32: 14)$. As it was mentioned above, the "voice" of God is sometimes compared to the lion's "roar." One has to consider especially the nearest context of chap. 31: in chap. 30 i is connected very clearly with the manifestation of divine power and the punishment for Assyria (30:30-31,

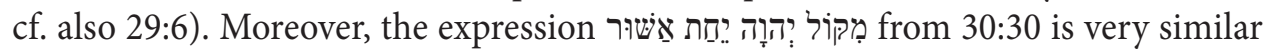

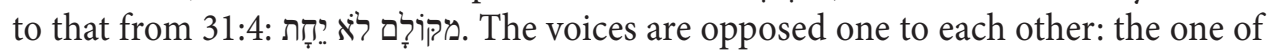
God "frightens" Assyria, the one of Assyria cannot "frighten" God. ${ }^{27}$ Certain irony

23 Cf. Sobierajski, "Mesjański ekosystem (Iz 11,6-8)," 132-133.

24 One can contradict the continuity of these prophecies and their messianic nature in relation to the expectations of the royal descendant. Their connection is primarily due to the common motif of the child and a number of elements belonging to the topos of the king and the monarchy. Texts from chap. 9 and 11 would be both autonomous prophecies and some kind of re-interpretation of the oracle of chap. 7 because Isaiah himself sought to understand the message of Emmanuel. More broadly, both their mutual relationship and the argumentation for their messianic character are discussed in: Pikor, "Pytanie o mesjański sens Izajaszowych proroctw," 15-36.

25 Cf. Wildberger, Isaiah 28-39, 221.

26 Oswalt, The Book of Isaiah, 574.

27 Both occurrences of the verb חָּ are in Ni can also be found in Isa 7:8; 8:9, and for this reason - for $\mathrm{H}$. Wildberger (Isaiah 1-12,351) - this verb belongs to the typically Isaianic vocabulary. The second verb עiָָ used here in its basic meaning "to be daunted" (Qal, but more often in Pi: "to humble, violate, degrade," e.g. Gen 34:2; Exod 22:21; Ps 94:5) and derives from the root (the homographic root both

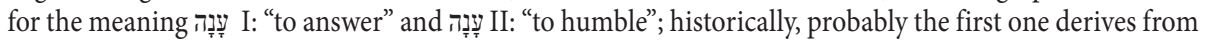
the original ענו עני and the second from there is no certainty about it). Cf. Gerstenberger, "עָנז II," TDOT XI, 231. 
of the changed roles in theophany can be seen: the divine appears, the people make noise, the divine does not frighten. ${ }^{28}$ The second noun הָמוֹ in in Isaiah, in the same nearest context, assigned to this hostile empire as well. Chap. 29 describes Assyr-

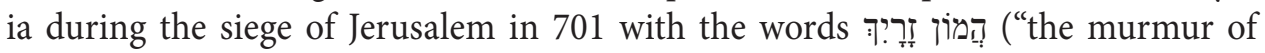

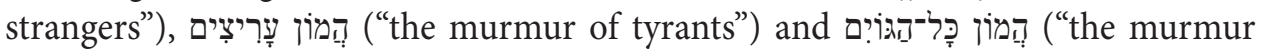
of all the nations") (29:5.7.8). In conclusion, one may find some ambiguity during the analysis of the vocabulary of the shepherds against which the lion appears. On the one hand, the shepherds can refer to the rulers and defenders in the capital, which the Kingdom of Judah expected, also among the other nations. On the other hand, there are clear references to the Assyrian army besieging Jerusalem during the $701 \mathrm{BCE}$ campaign. Isaiah seems to imply just at this point that $\mathrm{YHWH}-$ lion - is against both Assyria (and her king), and Jerusalem, specifically her rulers.

Taking into account these two analysis of "shepherds" and "their voice," one can show yet another possible allusion to be seen in this image. Shawn Z. Aster sees in the root (vv. 1.2.3) an Isaianic reference to the person of Azuri, king of Ashdod, who before 712 BCE ceased paying tribute for Assyria and encouraged the nearest kingdoms to form an anti-Assyrian coalition. The rebellion was smothered by Sargon, who conquered Ashdod and its neighboring cities. For sure also Judah was called to join the coalition. On the other hand, the root vר, returning twice (v. 2), invokes the Egyptian commander Re'u, whose superior was Shabaka. He, along with Iaubidi, king of Hamath, and Hanun, king of Gaza, developed a revolt against Assyria in about 722 BCE. In the battle at Rafiah, Sargon defeated the allied troops. These events influenced Judah and the neighboring kingdoms, which remained loyal to the Assyrian Empire at least until $716 \mathrm{BCE} .^{29}$ The abovementioned connotation between the root and the Egyptian commander Re'u also supports the fact, that his name was found in the inscription from 707 BCE (thirteen years after the battle at Rafiah):

Hanun, king of Gaza, together with Re'u, the turtenu [second-in-command] of Egypt, made battle and war against me at Rafiah. I smashed and defeated them. Re'u feared the noise of my weapons and fled, and his place is not seen

and that his name is written using the shepherd's logogram. Such an image corresponds to the irony of Isa 31:4: it is difficult to imagine that the voice of shepherds could frighten the beast, however, only the sound of Sargon's weapons was sufficient to make Re'u's escape, even without seeing the direct threat. ${ }^{30}$

\footnotetext{
28 Cf. Eidevall, "Lions and Birds as Literature," 84.

29 Cf. Aster, "Isaiah 31," 351-354.

30 Cf. (also the quotation of the inscription is after:) Aster, "Isaiah 31," 352. There is also another inscription from Khorsabad, in which the sentence is found: "Re'u, like a shepherd whose sheep was stolen, fled alone and went away."
} 
The second part of the comparison presents a major problem: how should we

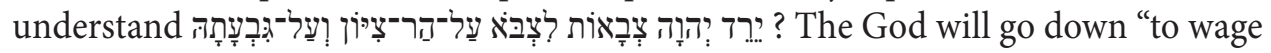
a war on the Mount Zion" or "to wage a war against Mount Zion"? Arguments for the first interpretation are as follows:

1. The ancient translation of the Vulgate: "super montem Zion." However, one must remember that the preposition "super" do not have the same ambiguity as עn Hebrew, so the translator had to choose one of the semantic options leaving the other one. ${ }^{31}$

2. The character of the whole speech. The second comparison speaks about the

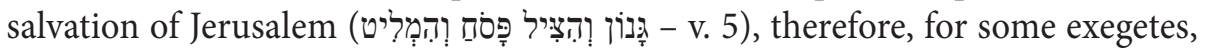
it is a clear signal that in the same spirit of salvation one should also read v. $4 .{ }^{32}$ However, also at this point we can ask: was v. 5 really the promise of salvation originally? For some exegetes it is for sure an redactional addition, representing the later stage in the development of the oracle: it transforms the preceding image of destruction into the promise of salvation. ${ }^{33}$

3. For the others, the image is not about the lion that pounces on its prey, but that protects its prey: "it will not allow anyone to steal from him what belongs to him"34; the same concerns the birds defending the city. However, there is no unanimity: Marvin A. Sweeney claims that "just as the lion protects his prey in order to eat it himself, so YHWH will protect Zion in order to punish it himself by bringing the Assyrians." ${ }^{35}$

Arguments for understanding עַ as the adversative preposition ("against") are as follows:

1. The syntax of the sentence, in which - if the author wanted to avoid any ambi-

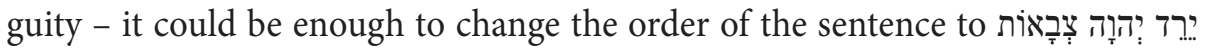

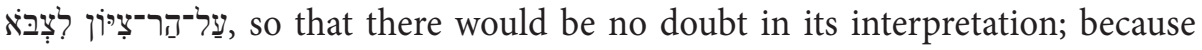

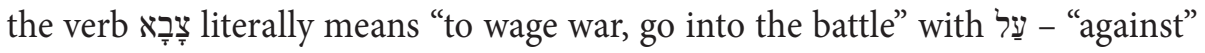
somebody (cf. Num 31:7; Zech 14:12). ${ }^{36}$

2. In the so-called "second beginning" of the Book of Isaiah (2:1), there is a passage (2:6-22) that seems to be a programmatic word for the whole Proto-Isaiah. The

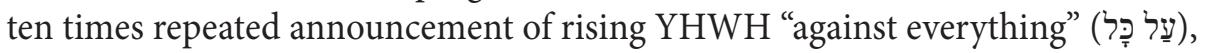
which is proud and exalted (2,12-16), underlines the divine judgement over the world. ${ }^{37}$ The proud "mortals" (2:9.17) are not only the leaders of Jerusalem or Assyria, but it can be every human (cf. 2:22).

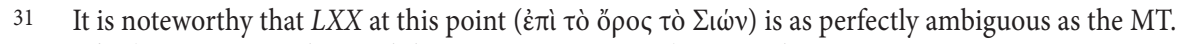

32 Cf. Clements, Jerusalem and the Nations, 91-92; Beuken, Isaiah II, 201-203.

33 Cf. Donner, Israel Unter den Völkern, 136; Childs, Isaiah, 58-59; Dietrich, Jesaja und die Politik, 183-185.

34 Kaiser, Isaiah 13-39, 316. Cf. Wildberger, Isaiah 28-39, 221.

35 Sweeney, Isaiah 1-39, 404-405. Cf. Exum, "Of Broken Pots," 338.

36 Cf. Childs, Isaiah, 58; Sweeney, Isaiah 1-39, 405; Roberts, First Isaiah, 404.

37 Cf. Sobierajski, Antropologiczny wymiar proroctw, 275-284.
} 
3. If YHWH is against everything that is proud and high, does this also include Zion and the holy city of Jerusalem? Chap. 29 dispels these doubts: Isa 29:4 defines Ariel

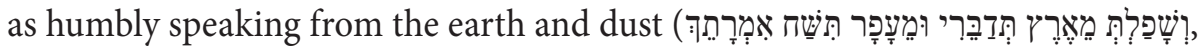

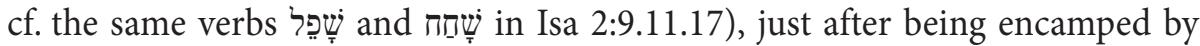
God. ${ }^{38}$

4. In the aforementioned context of pride one has to notice a strange definition

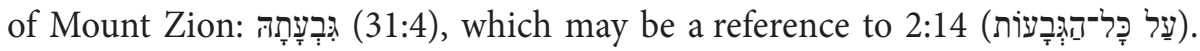
Firstly, there is only one more place in the Old Testament, in which Jerusalem is

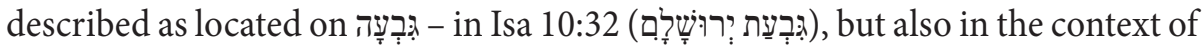

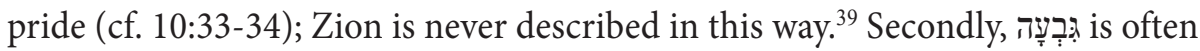
connected with the pagan-cult places (2 Kgs 14:23; 16:4; 17:10; Jer 2:20; 13:27; 17:2; Hos 4:13) and - especially in Isaiah - with pride (Isa 2:14 and as a verb in $2: 15 ; 3: 16 ; 5: 15.16 ; 10: 33)$. Therefore, it is rational to see the rising of God against the pride of Jerusalem in this verse, the attitude that is so often denounced by the prophet. ${ }^{40}$

5. Chap. 29 also shows clearly that God can fight against Jerusalem. ${ }^{41}$ The triple

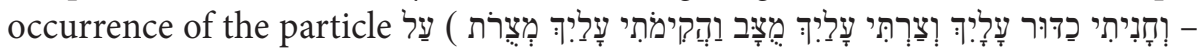
Isa 29:3) emphasizes the military situation of capturing the city, and also refers to 2:12-16.

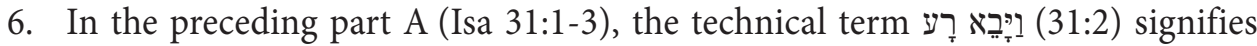
divine judgement, ${ }^{42}$ so one can expect such judgement in the nearest context.

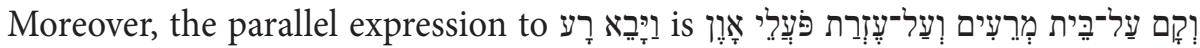
- preposition עַ repeated twice (here in the adversative meaning) seems to be undertaken exactly by עֵ from part B (v. 4); the divine judgement can also indicate

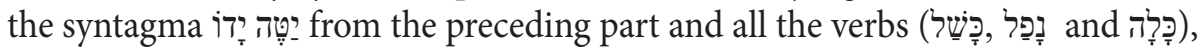
which describe the fall both of Judah and Egypt. Therefore, the reader may expect a more detailed explanation of their demolition.

7. As it was mentioned, the picture of the comparison brings a lion, who takes care about his loot, but finally this prey is to be consumed by him.

It seems that the ambiguity of the use of the preposition was intended by the author. ${ }^{43}$ On the one hand, the whole oracle can be read as a threat against Jerusalem because of the abovementioned arguments. Again, one has to notice that in

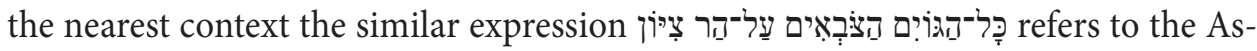
syrian invasion of Judah. Remembering about Assyrias alignment with the tool in

\footnotetext{
38 Cf. Sobierajski, Antropologiczny wymiar proroctw, 239-241.

39 One can think if Ezek 34:26 tells about the capital, but there is no clear indication of this.

40 Cf. Sobierajski, Antropologiczny wymiar proroctw, 51-65.

41 In the first part there is, in fact, a treatment both of the Egyptians and those who put their trust in them, as enemies of YHWH. Cf. Eidevall, Prophecy and Propaganda, 102.

42 Cf. Rick - Dohmen, "עער," TDOT XIII, 585-586.

43 Cf. Oswalt, The Book of Isaiah, 574.
} 
YHWH's hand, the divine "going into the battle against Mount Zion" can be read as an attack of the hostile empire on Jerusalem. Besides, the symbolism of the lion, which Isaiah very clearly applied to the Assyrian Empire, indicates this understanding of the prophecy. In the past, if the Isaiah's listeners heard about God's judgement that would come with the Assyrian army $(5: 26-30 ; 7: 18 ; 8: 7 ; 10: 6)$, compared to the lion (5:29), ${ }^{44}$ so in the present oracle (31:4-5) they would expect such a message from Isaiah: the God's punishment through Assyria is coming. But the second part of the comparison is not as they expected. There is no mention about Assyria, but about YHWH, who himself will fight against Zion, but also "on Mount Zion," at His own place. For the leaders of Jerusalem this was the oracle of judgement because they expected God's punishment by the hands of Assyria, for what they were prepared having entered into alliance with Egypt. The message from the prophet is quite different, announcing the intervention of God himself. Their plan was uncovered, their wisdom failed, so they cannot avoid punishment.

\subsection{The Metaphor of Birds}

The second comparison, which contains the image of birds, allows for many expla-

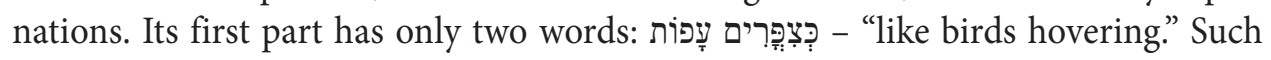
an image is blurred, hence producing many interpretations, for example:

1. "the birds hover over a young bird which has fallen out of the nest to defend it"

2. "a mother bird which flies back and forth over her nest when a predator is near, both to distract the enemy and, if necessary, to offer herself as a victim to save her little ones" $"$;

3. the scavenger birds that are attracted by the lion's killing because usually the lion does not eat its entire prey at once ${ }^{47}$;

4. "bird whose nest or whose food is threatened"48;

5. frightened birds fleeing away from danger"

6. large birds casting away their shadows over the city ${ }^{50}$.

44 Also, the listeners of Isaiah were probably well known in the images (e.g. of the lion) that hostile emperors applied to themselves. Cf. Machinist, "Assyria and Its Image," 735-736. See also the detailed example of such "Assyrian propaganda" in: Aster, “The Image of Assyria in Isaiah 2:5-22," 249-278.

45 Exum, "Of Broken Pots," 338. Cf. Hempel, Apoxysmata, 26-28.

46 Oswalt, The Book of Isaiah, 574. Cf. Goldingay, Isaiah, 177; Shemesh, "Isaiah 31,5," 256-260; Roberts, First Isaiah, 404.

47 Cf. Barré, "Of Lions and Birds," 58; Sweeney, Isaiah 1-39, 407; Beuken, Isaiah II, 202-203.

48 HALOT III, 1047; Blenkinsopp, Isaiah 1-39, 427.

49 Cf. Fohrer, Das Buch Jesaja, 121. Here the comparison to the birds is used in relation to the inhabitants of Jerusalem with their fearful behavior because of the oncoming Assyrian army. Otto Kaiser (Isaiah 13-39, 317) sees an omission here, the text could be: "like fluttering birds the nations will be scattered." 


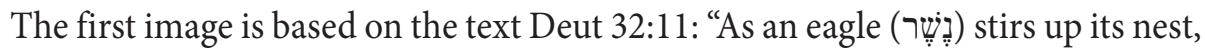

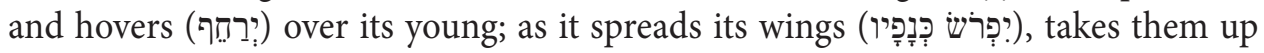

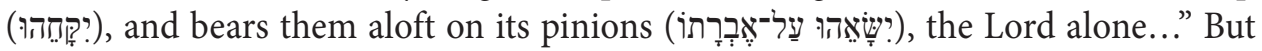
at this point, there are two problems. Firstly, the actions of the eagle are described by

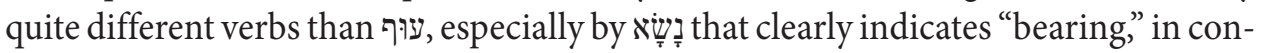
trast to Isa 31:5. Secondly, the noun רצ̣ refers generally to the birds (Gen 7:14; Lev 14:4; Ezek 39:4), or to the small birds like sparrows (Deut 22:6; Eccl 12:4), ${ }^{51}$ whereas, in Deut 32 is an eagle, and as far as one can find images of eagle carrying young on

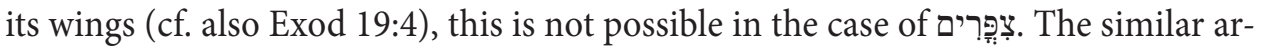
gument can be raised against cases (3), (4) and (6). The Old Testament uses another

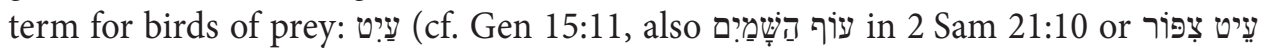
in Ezek 39:4), and it has to be expected that Isaiah, well versed in the natural world, ${ }^{52}$ would use it (cf. עn Isa 18:6 that is considered to be Isaianic). ${ }^{53}$ The case (2) is also

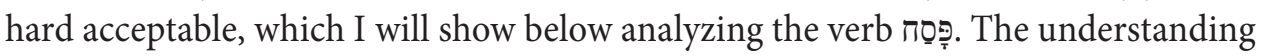

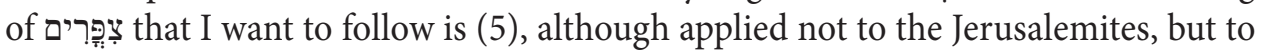
the besiegers. In such a sense, the verb עָכ would not mean simply "to hover" but "to fly away," a meaning which is confirmed in Ps 90:10 and Job 20:8 (also in Qal). The sense would be: just like sparrows, that could be very numerous, are flying away at once - frightened by something - and none of them remains, the same will be with the enemies of Jerusalem, e.g. with the grand and multitudinous Assyrian army (cf. Isa 37:36). Against this interpretation one can argue that "it is in fact YHWH himself who is being compared to the hovering birds." ${ }^{54}$ However, one can point to the fragments in Proto-Isaiah in which the essence of the metaphor lies in the overall condition of the compared entities. For instance, in Isa 10:15, the proud of the ax and of the saw is compared to the absurd situation of raising by the rod the one who lifts it up or lifting by the staff the one who is not wood (it does not matter whether we associate the axe/saw with the rod/staff). There is also a similar rhetorical device in Isa 29:8: the subject of the comparison (the vehicle of the metaphor) in this case is not the one who dreams, but the dream (cf. 29:7) with all its illusiveness (being hungry, dreaming about food and then waking up still hungry). Analogically, such a vehicle in Isa 31:5 are not the birds themselves, but their departure, and the tenor of the metaphor is saving Jerusalem.

In Isa 31:5 some kind of irony may be recognized. The birds are the symbol of weakness (Ps 11:1), unaware of danger they are trapped by their enemies (Prov 7:23; Lam 3:52) ${ }^{55}$ Sennacherib in his annals brags about Hezekiah: "Himself I made a pris-

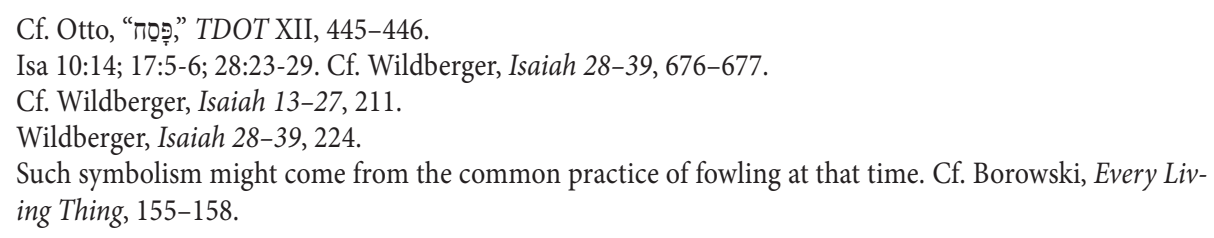


oner in Jerusalem, his royal residence, like a bird in a cage." ${ }^{56}$ If in the past the Assyrian king boasted that he had conquered the nations just like grasping a nest, like gathering eggs that have been forsaken (Isa 10:14), so now he and his army are equal to the departing birds. But there is one more interesting observation. Among

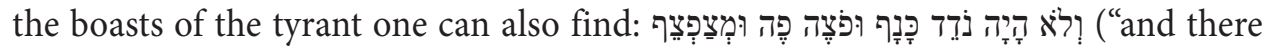
was none that moved a wing, or opened its mouth, or chirped" - 10:14). The last

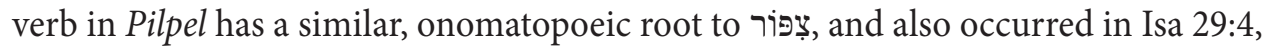

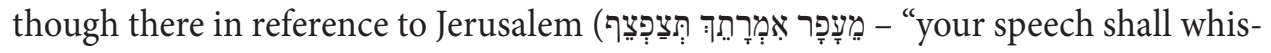
per out of the dust"). It seems that in this case Isaiah used intentional ambiguity as well: the birds could be the numerous Assyrian army that suddenly disappeared (Isa 37:36), but can also refer to the enemies of the will of YHWH inside the capital, among the Israelites. In fact, because of the similarly to the first comparison, the listeners of the prophet's oracle could at first impression (after hearing only the first

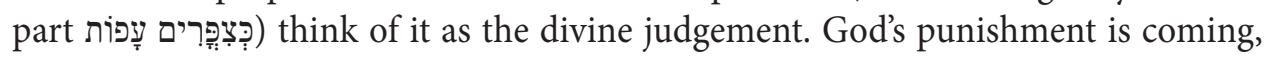
the Assyria like a lion is approaching, so all the nations - among them the Jerusalemites - will fly away like defenseless swallows. In their own opinion, they are prepared for such a situation - they have already made a covenant with Egypt. But also in this case, the second part of the comparison is unexpected for them. Isaiah announces the salvation of Jerusalem, though they have no idea how it will happen.

The above observations are confirmed by the analysis of the following four verbs making up the second part of the comparison. The verb iah and in Deutero-Zechariah, always in the sense of "defending" (Isa 37:35; 38:6 Zech 9:15; 12:8). The basic meaning - "to cover, surround, defend, protect" - can also be seen in confronting it with the noun ("shield" as a weapon), derived from the same root גנן (cf. e.g. 2 Chr 23:9). ${ }^{58}$ Immediately, however, the question arises: How could small birds be anybody's protection (in a shield manner)? As it has been said, a few proposition were made to resolve this problem. The birds could hover over a young bird or the nest or the food to defend it. But would it be possible that Isaiah chooses such small and weak animals as an example of the shield? Even if one assumes the meaning of "the scavenger birds" (which is doubtful), it would be difficult to demonstrate how this "hovering" over the prey could have a "protecting" character (e.g. if even human - Abram or Rizpah - could scare them in Gen 15:11 and in 2 Sam 21:10)? I claim that the nature of this protection lies in the understand-

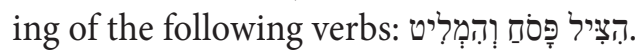

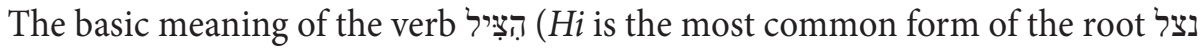
in the Old Testament) is "to take away" with the nuance of separation. As examples

56 ANET, 288 (fragment from Taylor Prism).

57 The same passages are in $2 \mathrm{Kgs}$ 19:34; 20:6. Regarding the mutual relations of both narrative sections 2 Kgs 18-20 and Isa 36-39 see e.g.: Beuken, Isaiah II, 335-341; Anderson, "The Rise, Fall, and Renovation," 147-167.

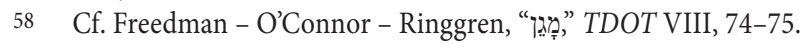


one can point to Gen 31:9.16 (God taking away the livestock), Hos 2:11 (with the parallel verb לְ? ) or Ps 119:43 ("Do not take the word of truth from my mouth!"). This understanding leads to the derivative meaning, i.e. "to save, to deliver" (e.g. Exod 3:8; Ps 142:7; Prov 10:2; Isa 19:20). However, even those fragments in which the root takes the meaning of "rescuing, saving, protecting", there exists the perceptible idea of "taking away." ${ }^{99}$ In the context of Proto-Isaiah, there are at least three important occurrences. Firstly, the group of verbs appears in the so-called historical addition (Isa 36-39), always in the meaning of rescuing the capital from the hand of the Assyrian king (cf. 36:14-20;37:11-12; 38:6). Secondly, in the announcement of the danger from the people that will come from the ends of the world (5:26-30), Assyria is

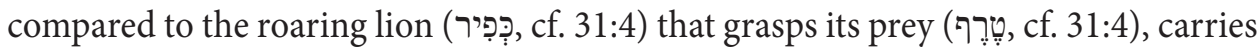

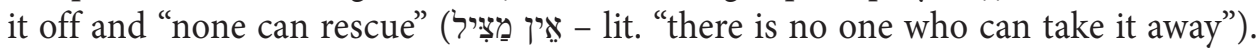
This action of course implies taking off the prey to eat it, i.e. to destroy it. Thirdly, in chap. 20, God calls Isaiah to walk naked and barefoot as a sign of leading away the Egyptian captives by the king of Assyria. At the end of the chapter, the inhabitants are complaining: "This is what has happened to those in whom we hoped and

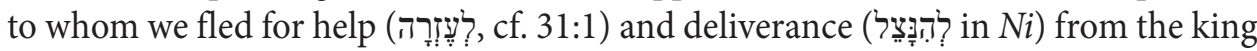
of Assyria! And we, how shall we escape (נִָּּ in $\mathrm{Ni}$, cf. 31:5)?” The Ni stem underlines the reciprocal aspect of the verbs here, that people want to act in their own favor to deliver and escape. Otherwise, in 31:5, both verbs are in Hi stem. It raises the question: can it show the causative aspect that only God can do the deliverance, in contrast to chap. 20? It is possible, however, one has to note that נצל does not occur in Qal, so it would be questionable to talk about the causative aspect without knowing anything about the meaning and even the existence of נצל in the base stem. The second verb המדליל, usually occurring in $\mathrm{Ni}$ ("to escape"), supports this theory; it has the $\mathrm{Hi}$ form only in two verses: Isa 31:5 and 66:7. In the latter, it means "to give birth to," so it can be understood as "to cause to escape" (from the mother's womb).

Very unusual and unexpected is the appearance of the verb noָ only here, in Isaiah (there are also two occurrences of the adjective פִ - "lame" in 33:23;35:6). Its basic meaning is "to be lame, to limp" (the use one can see in Elijah's rebuke: "How long will you go limping with two different opinions?" in $1 \mathrm{Kgs} \mathrm{18:21)}$ and the second one "to pass or spring over" (cf. Exod 12:13.23.27). ${ }^{60}$ Precisely because of these two options, there are also two tendencies to interpret the inf. abs. of Isa 31. The first one is based on the meaning "to be lame," understanding this action as hobbling, as the birds do when their nest is threatened. The parent bird limps away from the nest, pretending that one of its wings is broken and thus luring

\footnotetext{
59 Cf. Hossfeld - Kalthoff, "נצל", TDOT IX, 536.

60 Cf. Shemesh, "Isaiah 31,5," 258. However, there are many doubts if these two meanings derivate from two roots or a single root, as well as opinions about a mutual relation between them. For such attempts and also a very rich bibliography see: Otto, " "פָָָָ" 1-24.
} 
away the predator that sees an easy prey. ${ }^{61}$ The text Isa 37:7, in which God says about the Assyrian king: "I myself will put a spirit in him, so that he shall hear a rumor, and return to his own land; I will cause him to fall by the sword in his own land" is raised as an argument. So, in some sense, YHWH lured away Sennacherib from the capital and led him into his own country. In this attractive understanding we can, however, discern the following difficulties: (1) the verb פָָ means "to be lame" and not "to pretend being lame"; (2) there is a comparison to the birds, not one bird that usually uses such a distraction. Therefore, what fits much better fits is the second meaning "to pass over, to spare" also referring to the etiology of the Passover festival. Although in his preaching, Isaiah refers to the events of Exodus ${ }^{62}$ a few times, he makes no reference to the Paschal Night. However, this does not prove that the traditions of this festival were alien to him. This cannot be said with absolute certainty, but one can find an analogy between the passage of YHWH in Egypt (and the sparing of Israeli houses at the same time with slaying off the Egyptian firstborns - Exod 12:29) and the sparing of Jerusalem while the angel was passing through the Assyrian camp (Isa 37:36). "One cannot assume with absolute certainty that Isaiah is trying to remind the listeners of the Passover night," ${ }^{33}$ but for sure the specific character of the last two verbs

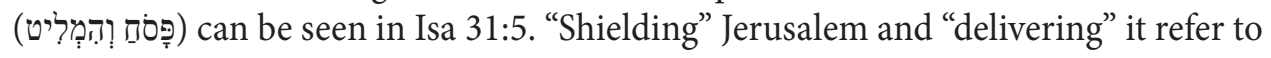
YHWH's passing over Jerusalem to spare it (פָסָ ) and causing all its enemies to "escape," i.e. to disappear (המדלִיט). What is important is that these enemies do not only include the besiegers, but also - this cannot be ruled out - some of the inhabitants of Jerusalem, which is testified in Isa 29:20 and 30:17 (with the verbs כָָ - "to finish," נוּ - "to flee," the same as in Isa 31:3.8).

\section{Conclusion}

The literary analysis carried out according to the rules of the Semitic rhetoric method has shown up the textual structure of Isa 31:1-9. The text has been divided into two main images: the fate of Israel, deviating from YHWH (vv. 1-5), and the fate of Israel, returning to YHWH (vv. 6-9). Although, each scene describes different situations, they are complementary and harmonizing. Furthermore, the structure reveals the internal dynamism of each scene: both have the element of the presentation of the actual condition (deviation from God or potential return to him), which is fol-

61 Cf. Keel, "Erwägungen," 430; Shemesh, "Isaiah 31,5," 259-260.

62 E.g. raising the staff over the sea (Isa 10:26; cf. Exod 14:26); raising the staff against the people (Isa 10:24; cf. Exod 2:11-12); the motif of "the wrath of the Lord" and "stretched hand" (Isa 5:25). Some of these verses are, however, treated as an editorial supplement. The theological motifs of Exodus are definitely more frequently pronounced in Hosea or Deutero-Isaiah. Cf. Wildberger, Isaiah 28-39, 578.

63 Wildberger, Isaiah 28-39, 224. 
lowed by the adequate result: God's rise against Israel (vv. 4-5) or against Assyria (vv. 7-9). Therefore, the understanding of the message conveyed by the animal metaphors has been read at two levels. The first one binds them with part A (vv. 1-3) from the causal point of view: the comparisons are expected to be the punishment for Israel. The second combines their significance with the look at the parallel part B' (vv. 7-9). The salvation presented there is not specified, nevertheless Assyria will fall by the sword, though the sword not of man (v. 8). Therefore, both the punishment for Jerusalem (B) and her salvation (B') will not occur according to the human thoughts.

The problem posed at the very beginning regarding the meaning of the phrase

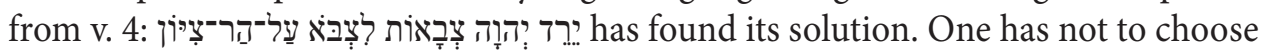
between the two translations: "YHWH shall go down to fight upon Mount Zion" or "against Mount Zion." Both meanings are acceptable; moreover, both of them were intended by Isaiah and are essential parts of his message. Yet, the ambiguity of the use of the preposition עy was intended. The listeners, hearing about the lion, would expect such a message from Isaiah: God's punishment through Assyria is coming... But the message from the prophet is quite different, announcing the intervention of God himself, not through Assyria. God himself is the lion and he is against both Assyria (and her king), and Jerusalem (her rulers and defenders). One can see a similar scheme in the second comparison in v. 5. The listeners, hearing about the birds, would understand the image this way: God's punishment by the hands of Assyria is coming and all the nations will fly away like sparrows... But the message is quite different, announcing the salvation of Jerusalem in yet an unknown way. The besiegers are the ones who will fly away, but the historical salvation of the capital in $701 \mathrm{BC}$ would mean at the same time the devastation of the defenders' plans. Hence, defenders' thoughts and intentions are also as fragile and fleeting as birds departing in an instant. The city is saved, so the alliance with Egypt turned out to be completely unnecessary.

The structure of the pericope and its exegesis reveal the main goal that guided the prophet transmitting God's message. It is most visible in v. 6, which was a direct appeal and had to convince the hearers, including the current readers of the Book of Isaiah, to rely only on YHWH. ${ }^{64}$ The key of the prophet's message is based on his individual and intimate encounter with YHWH. For him God is always "an almighty, absolutely demanding being, who could consume him and yet could set him free at the same time." ${ }^{65}$ This experience hasted the prophet to announce the divine message to his addressees with full energy and engagement, as well as with every possible mean, including shock and surprise shown by the incoherence of Isaiah's oracle, to convince his listeners.

64 Cf. Sweeney, Isaiah 1-39, 407.
65 Wildberger, Isaiah 28-39, 616. 


\section{Bibliography}

Albright, W.F., “The Babylonian Temple-Tower and the Altar of Burnt-Offering," Journal of Biblical Literature 39 (1920) 137-142.

Anderson, J.E., "The Rise, Fall, and Renovation of the House of Gesenius: Diachronic Methods, Synchronic Readings, and the Debate over Isaiah 36-39 and 2 Kings 18-20," Currents in Biblical Research 11 (2013) 147-167.

Aster, S.Z., "The Image of Assyria in Isaiah 2:5-22: The Campaign Motif Reversed," Journal of the American Oriental Society 127 (2007) 249-278.

Aster, S.Z., "Isaiah 31 as a Response to Rebellions against Assyria in Philistia," Journal of Biblical Literature 136 (2017) 347-361.

Barré, M.L., "Of Lions and Birds: A Note on Isaiah 31.4-5," Among the Prophets: Language, Image, and Structure in the Prophetic Writings (eds. D.J.A. Clines - P.R. Davies) (Journal for the Study of the Old Testament Supplement Series 144; Sheffield: Sheffield Academic Press 1993) 55-59.

Beuken, W.A.M., Isaiah II. II. Isaiah 28-39 (Historical Commentary on the Old Testament; Leuven: Peeters 2000).

Blenkinsopp, J., Isaiah 1-39. A New Translation with Introduction and Commentary (The Anchor Bible 19; New Haven, CT - London: Doubleday 2000).

Borowski, O., Every Living Thing. Daily Use of Animals in Ancient Israel (Walnut Creek, CA: AltaMira 1998).

Childs, B.S., Isaiah and the Assyrian Crisis (Study in Bible Theology 2/3; London: SCM 1967).

Childs, B.S., Isaiah (The Old Testament Library; Louisville, KY: Westminster John Knox 2001).

Clements, R.E., Jerusalem and the Nations. Studies in the Book of Isaiah (Hebrew Bible Monographs 16; Sheffield: Sheffield Phoenix 2011).

Dietrich, W., Jesaja und die Politik (Beiträge zur Evangelischen Theologie 74; München: Kaiser 1976).

Donner, H., Israel Unter den Völkern. Die Stellung der Kassischen Propheten des 8. Jahrhunderts v. Chr. zur Aussenpolitik der Könige von Israel und Juda (Vetus Testamentum Supplements 11; Leiden: Brill 1964).

Eidevall, G., "Lions and Birds as Literature. Some Notes on Isaiah 31 and Hosea 11," Scandinavian Journal of the Old Testament 7 (1993) 78-87.

Eidevall, G., Prophecy and Propaganda. Images of Enemies in the Book of Isaiah (Coniectanea Biblica. Old Testament Series 56; Winona Lake, IN: Eisenbrauns 2009).

Exum, J.C., "Of Broken Pots, Fluttering Birds and Visions in the Night: Extended Simile and Poetic Technique in Isaiah," The Catholic Biblical Quarterly 43 (1981) 331-352.

Feigin, S., “The Meaning of Ariel," Journal of Biblical Literature 39 (1920) 131-137.

Fohrer, G., Das Buch Jesaja. Band 2 - Kapitel 24-39, 2 ed. (Zürcher Bibelkommentare 19; Zürich - Stuttgart: Zwingli 1967).

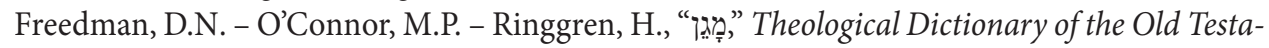
ment (eds. G.J. Botterweck - H. Ringgren - H.-J. Fabry) (Grand Rapids, MI - Cambridge: Eerdmans 1997) VIII, 74-87 (== TDOT). 


\section{ORACLE OF DOOM OR ORACLE OF SALVATION?A NEW INTERPRETATION}

Gerstenberger, E., "עָנָנָ II," Theological Dictionary of the Old Testament (eds. G.J. Botterweck H. Ringgren - H.-J. Fabry) (Grand Rapids, MI - Cambridge: Eerdmans 1997) XI, 230-252 $(==T D O T)$.

Godbey, A.H., "Ariel, or David-Cultus," The American Journal of Semitic Languages and Literatures 41 (1925) 253-266.

Goldingay, J., Isaiah (New International Biblical Commentary; Peabody: Hendrickson 2001).

Hempel, J., Apoxysmata. Vorarbeiten zu einer Religionsgeschichte und Theologie des Alten Testaments (Beihefte zur Zeitschrift für die alttestamentliche Wissenschaft 81; Berlin: Töpelmann 1961).

Hossfeld, F.-L. - Kalthoff, B., "נצלנ," Theological Dictionary of the Old Testament (eds. G.J. Botterweck - H. Ringgren - H.-J. Fabry) (Grand Rapids, MI - Cambridge: Eerdmans 1997) IX, 533-540 (== TDOT).

Irwin, W.H., Isaiah 28-33. Translation with Philological Notes (Biblica et Orientalia 30; Rome: Biblical Institute Press 1977).

Joüon, P. - Muraoka, T., A Grammar of Biblical Hebrew, 2 ed. (Subsidia Biblica 27; Roma: Biblical Institute Press 2006).

Kaiser, O., Isaiah 13-39. A Commentary (The Old Testament Library; Philadelphia, PA: Westminster 1974).

Keel, O., "Erwägungen zum Sitz im Leben des vormosaischen Pascha und zur Etymologie von

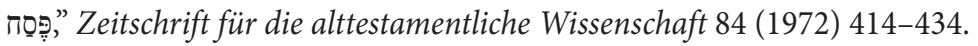

Koehler, L. - Baumgartner, W., The Hebrew and Aramaic Lexicon of the Old Testament (Leiden: Brill 1996) III (== HALOT).

van der Lugt, P., Cantos and Strophes in Biblical Hebrew Poetry. With Special Reference to the First Book of the Psalter (Oudtestamentische Studiën 53; Leiden - Boston, MA: Brill 2006).

Machinist, P., "Assyria and Its Image in the First Isaiah," Journal of the American Oriental Society 103 (1983) 719-737.

Meynet, R., Rhetorical Analysis. An Introduction to Biblical Rhetoric (Journal for the Study of the Old Testament Supplement Series 256; Sheffield: Sheffield Academic Press 1998).

Motyer, J.A., Isaiah. An Introduction and Commentary (The Tyndale Old Testament Commentaries 20; Leicester: Inter-Varsity 1999).

Nielsen, K., "I am Like a Lion to Ephraim. Observations on Animal Imagery and Old Testament Theology", Studia Theologica. Nordic Journal of Theology 61/2 (2007) 184-197.

Oppenheim, A.L. (trans.), "Babylonian and Assyrian Historical Texts," Ancient Near Eastern Texts Relating to the Old Testament, 3 ed. (ed. J.B. Pritchard) (Princeton: Princeton University Press 1969) 265-322 (== ANET).

Oswalt, J.N., The Book of Isaiah. Chapters 1-39 (The New International Commentary on the Old Testament; Grand Rapids, MI: Eerdmans 1986).

Otto, E., " - H.-J. Fabry) (Grand Rapids, MI - Cambridge: Eerdmans 1997) XII, 1-24 (== TDOT).

Pikor, W., "Pytanie o mesjański sens Izajaszowych proroctw o królewskim potomku. Część II: Iz 8,23b-9,6; 11,1-9," Zeszyty Naukowe KUL 50/2 (2007) 15-36.

Rick, D. - Dohmen, C., “רעע," Theological Dictionary of the Old Testament (eds. G.J. Botterweck - H. Ringgren - H.-J. Fabry) (Grand Rapids, MI - Cambridge: Eerdmans 1997) XIII, 560-588 (= TDOT). 


\section{BARTŁOMIEJ SOBIERAJSKI}

Roberts, J.J.M., First Isaiah. A Commentary (Hermeneia; Minneapolis, MN: Fortress 2015).

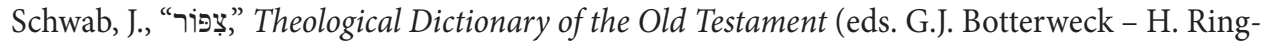
gren - H.-J. Fabry) (Grand Rapids, MI - Cambridge: Eerdmans 1997) XII, 443-449 $(=T D O T)$.

Seitz, C.R., Isaiah 1-39 (Interpretation. A Bible Commentary for Teaching and Preaching; Louisville, KY: Westminster John Knox 1993).

Shemesh, Y., "Isaiah 31,5: The Lord's Protecting Lameness," Zeitschrift für die alttestamentliche Wissenschaft 115 (2003) 256-260.

Sobierajski, B., "Mesjański ekosystem (Iz 11,6-8)," Verbum Vitae 31 (2017) 123-148.

Sobierajski, B., Antropologiczny wymiar proroctw o pysze Judy i Asyrii (Iz 1-39). Studium egzegetyczno-teologiczne (Studia Biblica Lublinensia 18; Lublin: Wydawnictwo KUL 2018).

Sobierajski, B., "«The name of YHWH comes from afar» (Isa 30:27) in the Light of Rhetorical Analysis of Isa 30:27-33: an Attempt at Identification," Biblica et Patristica Thoruniensia 12 (2019) 431-445.

Stansell, G., "Isaiah: 28-33: Blest Be the Tie that Binds (Isaiah Together)," New Visions of Isaiah (eds. R.F. Melugin - M.A. Sweeney) (Journal for the Study of the Old Testament Supplement Series 214; Sheffield: Sheffield Academic Press 1996) 68-103.

Sweeney, M.A., Isaiah 1-39. With an Introduction to Prophetic Literature (The Forms of the Old Testament Literature 16; Grand Rapids, MI: Eerdmans 1996).

Tawil, H., "El león y las aves: Isaías 31:4-5 a la luz de nuevas inscripciones neo-asirias," Antiguo Oriente 11 (2013) 155-165.

Waltke, B.K. - O'Connor, M.P., An Introduction to Biblical Hebrew Syntax (Winona Lake, IN: Eisenbrauns 1990).

Watts, J.D.W., Isaiah 1-33, 2 ed. (Word Biblical Commentary 24; Nashville, TN: Nelson 2005).

Wildberger, H., Isaiah 1-12. A Commentary (Continental Commentaries; Minneapolis, MN: Fortress 1991).

Wildberger, H., Isaiah 13-27. A Continental Commentary (Continental Commentaries; Minneapolis, MN: Fortress 1997).

Wildberger, H., Isaiah 28-39. A Continental Commentary (Continental Commentaries; Minneapolis, MN: Fortress 2002).

Youngblood, R., "Ariel, "City of God»", Essays on the Occasion of the Seventieth Anniversary of The Dropsie University (1909-1979) (eds. L. Nemoy - A.I. Katsh) (Philadelphia, PA: Dropsie University 1979) 457-462.

Zimmerli, W., Ezekiel 2. A Commentary on the Book of the Prophet Ezekiel. Chapters 25-48 (Hermeneia; Philadelphia, PA: Fortress 1983). 